\title{
The Effect of Cooperative Learning Type Team Assisted Individualization Assisted by Teaching Aids on Students' Mathematical Representation Ability
}

\author{
Isni Maulia Pancasilawati ${ }^{*}$, Habibullah², Salviana ${ }^{3}$ \\ ${ }^{1}$ Mathematics Teacher, SMP Negeri 30 Batam \\ ${ }^{2}$ Mathematics Teacher, SMP IT Imam Syafi'i Batam \\ ${ }^{3}$ Mathematics Teacher, SMP Negeri 42 Batam
}

*Corresponding author: isnibsp@gmail.com

\begin{tabular}{l}
\hline $\mathbf{r} \mathbf{i} \mathbf{i} \mathbf{i} \mathbf{i} \mathbf{0}$ \\
\hline How to cite this article: \\
Pancasilawati, A.M, Habibullah \& Salviana. \\
(2020). The Effect of Cooperative Learning Type \\
Team Assisted Individualization Assisted by \\
Teaching Aids on Students' Mathematical \\
Representation Ability. Eduma : Mathematics \\
Education Learning And Teaching, 9(2), 49 - 56. \\
doi: http://dx.doi.org/10.24235/eduma.v9i2.7259
\end{tabular}

Article history:

Received: 10 22, 2020

Accepted: 11 17, 2020

Published: 12, 2020

\section{Copyright (C) 2020}

EduMa: Mathematics Education Learning and Teaching under the Creative Commons Attribution 4.0 International License.

\author{
a b s t r a c t
}

THE EFFECT OF COOPERATIVE LEARNING TYPE TEAM ASSISTED INDIVIDUALIZATION ASSISTED BY TEACHING AIDS ON STUDENTS' MATHEMATICAL REPRESENTATION ABILITY. This research aimed to know the effect of cooperative learning type team assisted individualization assisted by teaching aids on students' mathematical representation ability. The research method used was a quasi-experiment with a one-group pretest-posttest design. The subjects of this research were 33 students from one of the State Junior High School in Cirebon using a sampling technique, namely purposive sampling but not using a control class. The data collection technique were carried out by pretest, posttest, and student activity observation sheets. The research data were analyzed using the average gain score analysis and correlation test. The results showed that there were an effect of cooperative learning type team assisted individualization assisted by teaching aids on students' mathematical representation ability. This can be seen from the increase in the mathematical representation ability of students at each evaluation that has been carried out with an increase in the average value of 51.61, and the student activity process that has increased at each meeting with an average percentage gain of $76.03 \%$ with a good category.

\section{Ke y word s :}

Cooperative Learning, Team Assisted Individualization, Teaching Aids, Mathematical Representation Ability. 


\section{INTRODUCTION}

Reys, Lindquist, Lambdin, \& Smith (2009) stated that mathematics is a language that uses carefully defined terms and symbols. Whereas, Walle (2007) stated that mathematics is the science of patterns and rules. Meanwhile, The National Council of Teachers of Mathematics (NCTM) (2000) explained that learning mathematics is learning about understanding mathematical ideas and learning about gaining skills and insights to solve problems.

According to Haylock \& Thangata (2007) the use and application of mathematics in learning has three series, namely learning to solve problems both in real life and in mathematics itself, developing communication skills using language and mathematical symbols, and developing skills to reason mathematically. The use and application of mathematics are one of the seven main areas of learning mathematics, now presented under five themes: problem-solving, representation, questioning, reasoning, and communication.

Mathematics lessons are very important for all students to master. So mathematics learning should receive serious attention so that the quality of mathematics learning can be improved. To realize this, teachers should be able to create a conducive climate for learning mathematics in the classroom so that students' mathematics learning outcomes can achieve the expected learning completeness (Habibullah, Puspitarani, \& Prasetyo, 2020).

One of the cognitive aspects that are thought to have a significant influence on learning mathematics is the ability of mathematical representation. The importance of the ability of mathematical representation can be seen from the statement of NCTM (2000) that in mathematics learning there are five standard processes must be mastered by students, namely problem solving, reasoning and proof, communication, connection, and representation. Representative ability is the ability needed by students to find and express mathematics in a way so that it can make it easier for students to understand the concept of a mathematics.

Kowiyah \& Mulyawati (2018) stated that mathematical representativeness is a method for communicating mathematical ideas through visual means in the form of numbers or tables, mathematical expressions, and equations. Whereas, according to Kartini (2009) the ability of mathematical representation is the ability to express mathematical ideas (problems, statements, solutions, definitions, etc.) into one of the following forms: (1) Images, graphs, or tables; (2) Mathematical notation, algebraic symbols; and (3) written text, as an interpretation of his thoughts. Meanwhile, Hwang, Chen, Dung, \& Yang (2007) explain that the meaning of representation can be different in different contexts. There are external representations (real world) and internal representations (thoughts). NCTM (2000) explained that the representations raised by students are expressions of mathematical ideas or ideas displayed by students to find a solution to the problems they are facing. Several studies have shown that good students' mathematical representation skills are the key to obtaining successful solutions in problemsolving (Gagne, 1985; Mayer, 1992).

However in reality at school, students are still weak in the ability of mathematical representation, this is in line the with research of Wahyudin (1999) which was founded several weaknesses that students have in solving mathematical problems, including: (1) a lack of understanding in using rules precise mathematical rules; (2) lack of good deductive thinking skills so that if they are given a mathematical problem with the theme of proving, indication, or show, they will have difficulty writing down the steps; (3) lack of ability to solve problems using logical procedures or steps so that all they think of is the final result obtained but they do not care about the steps or procedures; and (4) 
seldom check or listen back to an answer obtained (Minarti \& Senjayawati, 2015).

One of the reasons for the weak mathematical representation ability of students is because teaching and learning activities do not involve students actively. Also, the influence of teachers who always rely on conventional learning processes causes students to be lazy in identifying a problem (Muhamad, 2016). So, the teacher is still the center of learning, this causes students to be inactive and only know the concept, but do not understand the material and some students still follow the steps to solve the sample questions given by the teacher to work on similar practice questions with sample questions. This causes the ability of students to understand and represent mathematically not optimal.

To overcome this, the teacher needs to apply a learning model that can to build students to participate actively during the learning process in the classroom (Irvan, Jerusalem, \& Habibullah, 2020). One of the learning methods that can make students active is cooperative learning. The cooperative learning method will make students work together in doing structured tasks and discussing each other to lead to good learning interactions.

One type of cooperative learning that can be implemented so that students have mathematical representation abilities is the type of team assisted individualization. According to Suprihatiningrum (2013) this type of cooperative learning model emphasizes that individuals who do not understand the material are the responsibility of other group members so that members who already understand need to assist group members who do not understand. This is in line with the research of Safrin, Anggo, \& Sani (2018) which said that team assisted individualization type cooperative learning is designed to overcome student learning difficulties individually, where students learn at their own ability level. If they have qualified for a certain ability, they can build a solid foundation before going to the next stage.

\section{METHODS}

The form of this research is a quasiexperiment with research that is close to a real experiment but does not uses a control class. So that in this study only use one class as the experimental class. The subjects of this study were 33 students from one of the state junior high schools in Cirebon who were determined using a purposive sampling technique.

The design used in this study is in the form of a one-group pretest-posttest design, which is as follows.

Table 1

Experimental Research Design

\begin{tabular}{ccc}
\hline Pretest & Treatment & Posttest \\
\hline $\mathrm{O}_{1}$ & $\mathrm{X}$ & $\mathrm{O}_{2}$ \\
\hline
\end{tabular}

Information:

$\mathrm{X}$ : The treatment in the experimental group was cooperative learning type team assisted individualization assisted by teaching aids.

$\mathrm{O}_{1}$ : Initial test or pretest value (before being given treatment).

$\mathrm{O}_{2}$ : Final test or posttest scores (after treatment).

The data collection techniques used in this study were test students' mathematical representation abilities and observation sheets. Data in the form of test results will be carried out by statistical tests, namely normality tests and correlation tests to determine whether there is an increase in students' mathematical representation abilities. While the data in the form of an observation sheet are used to determine student activities in implementing cooperative learning type team assisted individualization assisted by teaching aids.

To find out the observed student activities during the learning process, the percentage technique is used. The interpretation of the percentage of student activity can be seen in the following table. 
Table 2

Benchmark Percentage and Criteria for Student Activities

\begin{tabular}{ccc}
\hline No & Percentage & Criteria \\
\hline 1 & $90 \leq N_{\text {students }} \leq 100$ & Very Good \\
2 & $70 \leq N_{\text {students }}<90$ & Good \\
3 & $50 \leq N_{\text {students }}<70$ & Good Enough \\
4 & $30 \leq N_{\text {students }}<50$ & Not Good \\
5 & $0 \leq N_{\text {students }}<30$ & Very Poor \\
\hline
\end{tabular}

Source: (Jihad \& Haris, 2010)

\section{RESULT AND DISCUSSION}

The data from this research were obtained through the activities of the pretest, posttest, and the experimental class student activity observation sheets. Data from the pretest and posttest results will be used to determine whether there is an increase in the ability of students' mathematical representation after learning using cooperative learning type team assisted individualization assisted by props. The following are the results of pretest and posttest students' mathematical representation abilities.

Table 3

The Results of Pretest and Posttest Students' Mathematical Representation Abilities

\begin{tabular}{ccccc}
\hline & N & Minimum & Maximum & Average \\
\hline Pretest of Mathematical Representation & 33 & 13 & 38 & 23.06 \\
Posttest of Mathematical Representation & 33 & 53 & 91 & 74.67 \\
\hline
\end{tabular}

Based on Table 3, it can be seen that there were 33 students who took the test. The largest score for the pretest students' mathematical representation ability was 38 and the smallest score was 13 . While the largest score for the posttest students' mathematical representation ability was 91 and the smallest score was 53 . Furthermore, the pretest average score for the students' mathematical representation ability was 23.06 and the average posttest was 74.67 , so there was an increase in the mathematical representation ability of the students by 51.61 . Thus, it can be said that there is an increase in students' mathematical representation ability in cooperative learning type team assisted individualization assisted by teaching aids.

Meanwhile, the improvement of students' mathematical representation abilities can also be seen from the results of observations of student activities from the initial meeting to the end. The learning material used is the fraction number which includes the definition of fractions, types of fractions, operations on fraction numbers, as well as percent and decimal forms. In the learning process, students are given teaching aids. The teaching aids at the first meeting were a fraction ruler and a fraction card of the same rank. Fractional number ruler made of cardstock tied with a paper written with the value of fractions and dots. This aims to make students active in answering how many fraction values are correct to fill in the dots on the paper. The following shows the fraction ruler teaching aids.

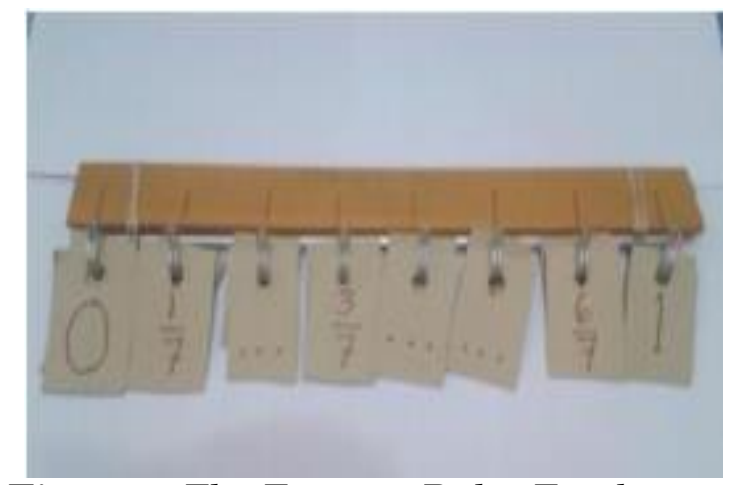

Figure 1 The Fraction Ruler Teaching Aids

In addition to the fraction ruler, the teaching aid that was also used at the first meeting was a fraction card of the same value so that students could actively discuss with their groups and be able to 
distinguish between types of fractions, especially finding fractions with as many values as possible. The following is a fraction card teaching aids.

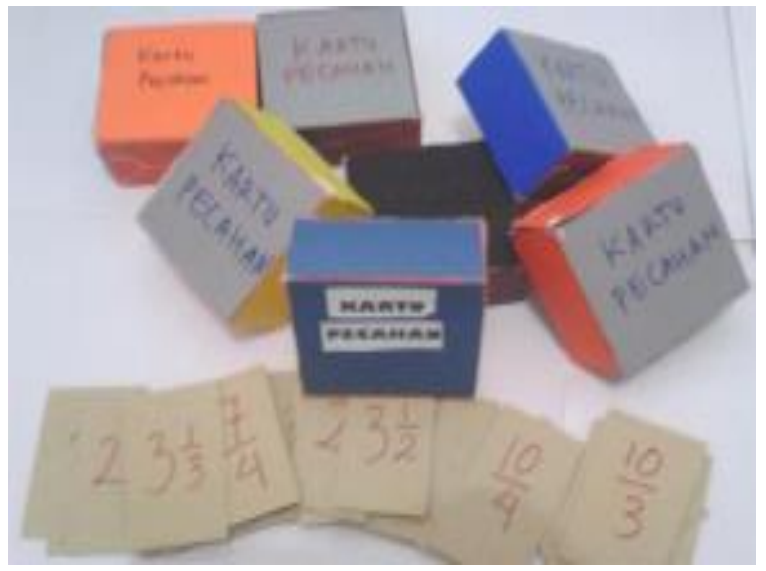

Figure 2 The Fraction Card Teaching Aids

Furthermore, the teaching aids at the second meeting were folding paper to find the sum. While the props at the third meeting were also the same, namely folding paper but aimed to find the multiplication of 2 fractions. Below is a picture of the folding paper teaching aids.
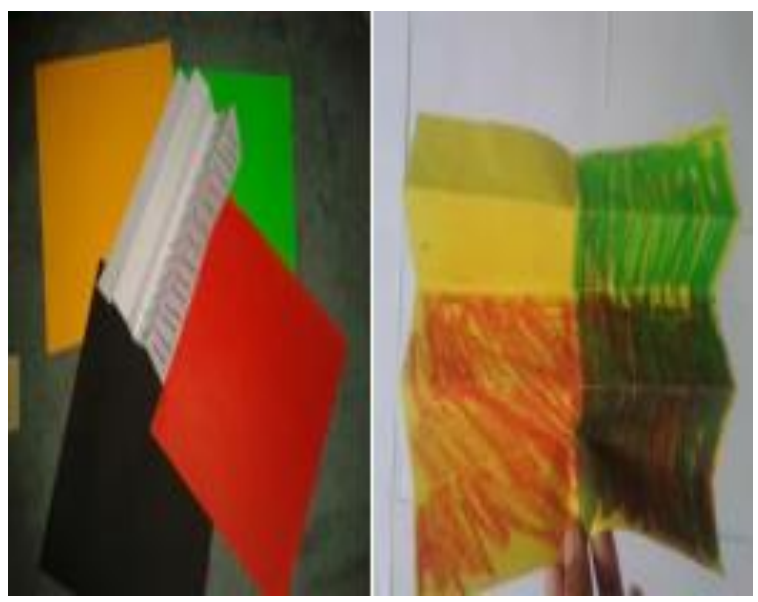

Figure 3 The Folding Paper Teaching Aids

Meanwhile, the teaching aids at the fourth meeting were two pieces of cardboard shards, this is to make students actively ask questions and be able to change the form of fractions to decimal and percent. The following is a picture of a fraction cardboard teaching aids.

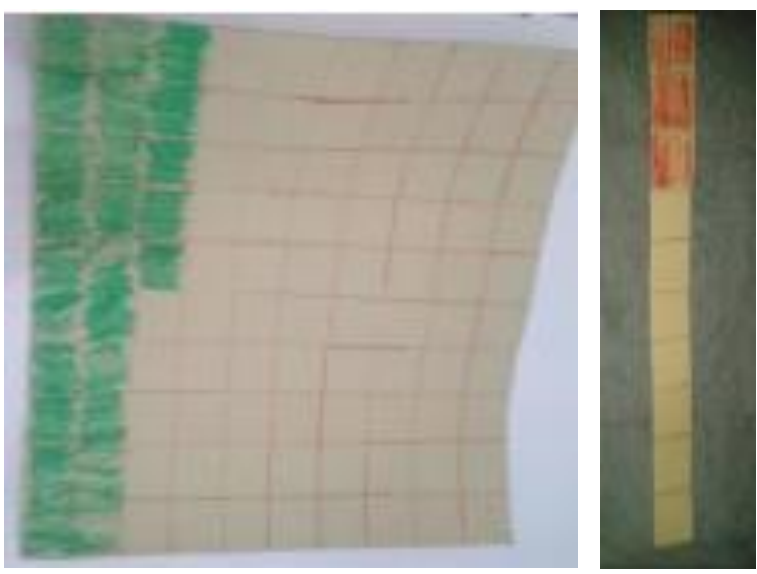

Figure 4 The Fraction Cardboard Teaching Aids

The results of increasing student activity during the learning process are presented in the following graphic.

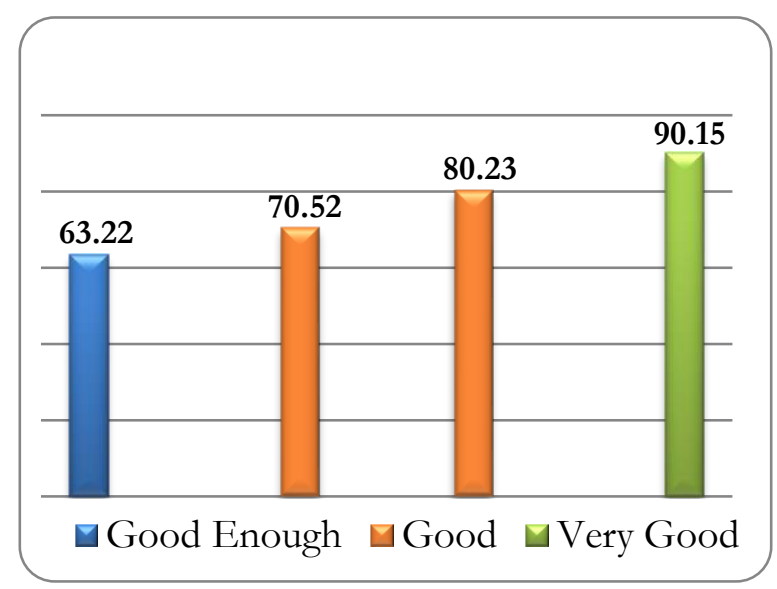

Figure 5 Graph of Student Activity Results

Based on Figure 5, it can be seen that there has been an increase in student activity from each meeting. At the first meeting of cooperative learning type team assisted individualization assisted by teaching aids, the percentage of student activity was found to be $63.22 \%$ with good enough category. It is because students are still embarrassed in interacting with their teachers and friends. Furthermore, at the second meeting there was an increase in student activity with a percentage of $70.52 \%$ in the good category. Whereas, at the third meeting, student activity increased with a percentage of $80.23 \%$ in the good category. Meanwhile, at the fourth meeting, student activity also increased with a percentage of $90.15 \%$ 
which was categorized as very good. This is because students are able to understand and get used to implementing the learning process that is being carried out. So, it can be said that there is an increase in student activity during the learning process of cooperative learning type team assisted individualization assisted by teaching aids with an average percentage gain of $76.03 \%$ in a good category.

Then, to determine the relationship between the application of cooperative learning type of team assisted individualization assisted by teaching aids and the ability of students' mathematical representation, a correlation test is necessary. However, before conducting the test analysis, the normality test will be carried out first. The results of the calculation of the pretest and posttest data normality test of students' mathematical representation abilities are presented in the following table.

Table 4

The Results of Data Normality Test for Pretest and Posttest Students' Mathematical Representation Ability

\begin{tabular}{cccc}
\hline & \multicolumn{3}{c}{ Kolmogorov-Smirnov $^{\mathrm{a}}$} \\
\cline { 2 - 4 } & Statistic & $\mathrm{df}$ & Sig. \\
\hline Pretest of Mathematical Representation & 0.105 & 33 & $0.200^{*}$ \\
Posttest of Mathematical Representation & 0.129 & 33 & $0.179^{*}$ \\
\hline
\end{tabular}

Based on Table 4, information is obtained that the results of the data normality test using the Kolmogorov-Smirnov test with the assumption that if the significance value is $>0.05$, it is concluded that the student's pretest and posttest data comes from data that is normally distributed. Conversely, if the significance value is $\leq$ 0.05 , it can be concluded that the student's pretest and posttest data comes from data that is not normally distributed. For pretest data, a significance value of $0.200>$ 0.05 is obtained, while for post-test data a significance value is obtained for $0.179>$ 0.05 . Thus, it can be concluded that the pretest and posttest data on students' mathematical representation abilities comes from data that is normally distributed.

After the data is normally distributed, to determine the correlation of the variables in this study, the Pearson correlation test is used which aims to determine the relationship between the paired scores is positive or negative or both have a strong relationship (Ary, Jacobs, \& Sorensen, 2010). The results of the calculation of the correlation test between cooperative learning type team assisted individualization assisted by teaching aids with the ability of students' mathematical representation are as follows. 
Table 5

The Results of Correlation Test Output between Cooperative Learning Type Team Assisted Individualization Assisted by Teaching Aids with Students' Mathematical Representation Ability

\begin{tabular}{clcr}
\hline & & Activity Posttest of Mathematical Representation \\
\hline Activity & Pearson Correlation & 1 & $0.777^{* *}$ \\
& Sig. (2-tailed) & & 0.000 \\
& $\mathrm{~N}$ & 33 & 33 \\
Posttest of & Pearson Correlation & $0.777^{* *}$ & 1 \\
Mathematical & Sig. (2-tailed) & 0.000 & \\
Representation & $\mathrm{N}$ & 33 & 33 \\
& &
\end{tabular}

From Table 5, it can be obtained information that the value of the correlation coefficient (r) between cooperative learning type team assisted individualization assisted by teaching aids and the mathematical representation ability of students is 0.777 with a significance level of 0.000 . Based on predetermined criteria, because the significance value is $0.000<0.05$, it can be concluded that there is a relationship between cooperative learning type team assisted individualization assisted by teaching aids and the students' mathematical representation ability. While the coefficient of determination ( $R$ Square) obtained is 0.60 . This shows that the independent variable affects the dependent variable by $60 \%$.

With an increase in the ability of mathematical representation and student activities, it can be said that cooperative learning type team assisted individualization assisted by teaching aids is an alternative for teachers in creating a conducive learning environment to improve students' mathematical representation ability. This statement is supported by the research of Safrin et al. (2018) which explained that there is a significant increase in the ability of students' mathematical representation through the application of team assisted individualization type cooperative learning. Because, according to Sabirin (2014) the ability of mathematical representation is one of the abilities that is very useful for students in solving a problem more easily, because it functions as a means of communicating students' mathematical ideas or ideas to teachers and other students.

\section{CONCLUSION AND IMPLICATION}

Based on the increase in the mathematical representation ability of students at each evaluation that has been carried out with an increase in the average value of 51.61, as well as the student activity process that has increased at each meeting with an average percentage gain of $76.03 \%$ with a good category, it can be concluded that there is an effect of cooperative learning type team assisted individualization assisted by teaching aids on students' mathematical representation ability.

At the time of implementing the learning process in the classroom, there were still several obstacles experienced by both students and teachers. These constraints are that the teacher has not been able to discipline students at the time of group formation so that learning has not gone according to the planned time allocation. In addition, when viewed by students, they still experience confusion when correcting the work results of their friends' questions. Therefore, the teacher should prepare the answer keys and scoring guidelines. The answer key is given to each student in a group when all students from each group have finished working on the description questions to prevent students from cheating. 


\section{REFERENCES}

Ary, D., Jacobs, L. C., \& Razavieh, A. (2010). Introduction to research in education 8th edition, Wardswoth Cengage Learning. Canada: Nelson Education Ltd Exotic Classic.

Gagne, E. D. (1985). The cognitive psychology of school learning. Boston: Brown and company.

Habibullah, H., Puspitarani, P., \& Prasetyo, H. (2020). Mathematical Self-Efficacy of Students in Cooperative Learning With Two Stay Two Stray Technique. PYTHAGORAS: Jurnal Program Studi Pendidikan Matematika, 9(1), 71-76

http://dx.doi.org/10.23887/jipm.v11i1.2 $\underline{3609}$

Haylock, D., \& Thangata, F. (2007). Key concepts in teaching primary mathematics. London: SAGE Publications.

Hwang, W. Y., Chen, N. S., Dung, J. J., \& Yang, Y. L. (2007). Multiple representation skills and creativity effects on mathematical problem solving using a multimedia whiteboard system. Journal of Educational Technology \& Society, 10(2), 191-212. Retrived from https://www.jstor.org/stable/10.2307/je ductechsoci.10.2.191

Irvan, M. F., Jerusalem, M. A., \& Habibullah. (2020). The mathematics learning model's for early grade students: Contextual or problem-based learning. AKSIOMA: Jurnal Program Studi Pendidikan Matematika, 9(3), 551-560.

https://doi.org/https://doi.org/10.24127/ ajpm.v9i3.2779

Jihad, A., \& Haris, A. (2010). Evaluasi Pembelajaran. Yogyakarta: Multi Pressindo.

Kartini. (2009). Peranan representasi dalam pembelajaran matematika. In Seminar Nasional Matematika dan Pendidikan Matematika UNY (pp. 361-372).

Kowiyah, \& Mulyawati, I. (2018). An Analysis of Primary School Students' Representational Ability in mathematics based on gender perspective. Journal of Physics: Conference Series, 948(12016), 1-8. https://doi.org/10.1088/1742- $\underline{6596 / 948 / 1 / 012016}$

Mayer, R. E. (1992). Thinking, problem solving, cognition. New York: W. H. Freeman and Company

Minarti, E. D., \& Senjayawati, E. (2015). Studi Komperatif Penerapan Pendekatan Kontekstual Dan Pendekatan Kontekstual Bersetting Pembelajaran Cooperative Script Terhadap Kemampuan Representasi Matematis dan Self Confidence Siswa Smk Di Kota Cimahi. Jurnal Ilmiah P2M STKIP Siliwangi, 2(2), 169-181. https://doi.org/10.22460/p2m.v2i2p169 $-181.176$

Muhamad, N. (2016). Pengaruh metode discovery learning untuk meningkatkan representasi matematis dan percaya diri siswa. Jurnal Pendidikan Universitas Garut, 9(1), 922.Retrived from http://journal.uniga.ac.id/index.php/JP /article/view/83

NCTM. (2000). Principle and standards for school mathematics. Reston, VA: The National Council of Teachers of Mathematics, Inc.

Reys, R., Lindquist, M. M., Lambdin, D. V, \& Smith, N. L. (2009). Helping children learn mathematics (9th ed.). New York: John Wiley \& Sons, Inc.

Sabirin, M. (2014). Representasi dalam pembelajaran matematika. Jurnal Pendidikan Matematika (JPM) IAIN Antasari, 1(2), 33-44. http://dx.doi.org/10.18592/jpm.v1i2.49

Safrin, Anggo, M., \& Sani, A. (2018). Peningkatan Kemampuan Representasi Matematis Siswa SMP Melalui Penerapan Model Pembelajaran Kooperatif Tipe Team Asissted Individualization (TAI) dengan Pendekatan Saintifik. Jurnal Pembelajaran Berpikir Matematika, 3(1), 13-24. http://dx.doi.org/10.33772/jpbm.v3i1.7 $\underline{236}$

Suprihatiningrum, J. (2013). Strategi pembelajaran: Teori \& aplikasi. Yogyakarta: Ar Ruzz Media.

Walle, J. A. Van de. (2007). Elementary and middle school mathematics: Teaching developmentally. Boston: Pearson Education, Inc. 